\title{
Листування Марка Вовчка: невирішені питання атрибуції, датування та коментування
}

\author{
Abstract \\ Marko Vovchok's Correspondence: Unsolved Issues of Attribution, Dating \\ and Commenting
}

The article deals with the publication of a part of the collection of Marko Vovchok's letters dating back to early years of the $20^{\text {th }}$ century. In particular, it studies Vasyl Domanytsky's letters to Marko Vovchok and her letters in reply to him. The story of publishing of the writer's letters started in 1920s. The fourth volume of Marko Vovchok's Stories (1928) edited by Oleksandr Doroshkevych contained, among others, 98 letters written by the author to various people and 120 letters addressed to her. Insufficient studying of Marko Vovchok's collection of letters caused a number of mistakes concerning their attribution in the edition, in particular, her letters to Vasyl Domanytsky were mistakenly attributed as letters to Fedir Matushevsky. The editors corrected this mistake in later editions, but they made some other mistakes during the preparation of the edition. The six letters from Vasyl Domanytsky that are analyzed here, were first published in Letters to Marko Vovchok (1979).

Currently, 694 Marko Vovchok's letters and 527 letters addressed to her are published and available to scholars. The detailed analysis of this collection of letters rises a number of questions that need to be answered. Upon reading carefully correspondence between Marko Vovchok and Vasyl Domanytsky and notes to them as well as comparing their letters to their biographies, the author of the article suggests re-attributing some of the writer's letters addressed to Vasyl Domanytsky, Volodymyr Naumenko, and Fedir Matushevsky.

The article also highlights incorrect commenting of some realia that are mentioned in the letters, which is often caused by incorrect dating. The offered version corresponds fully to well-known facts from the writer's biography and eliminates inconsistencies that were caused by incorrect attribution.

Keywords: manuscript, Vasyl Domanytsky, Fedir Matushevsky, Volodymyr Naumenko, magazine "Kievskaya Starina", correspondence, attribution, dating, commenting

Ключові слова: рукопис, Василь Доманицький, Федір Матушевський, Володимир Науменко, журнал «Киевская старина», листування, атрибуція, датування, коментування 
Публікація епістолярію Марка Вовчка має тривалу традицію. Приватний лист письменниці, що його було вперше оприлюднено для широкого загалу, - це лист до Тараса Шевченка, надрукований у липневому числі журналу «Основа» за 1861 рік.

До видання творів письменниці листи вперше включив Богдан Лепкий (1926). Через два роки, готуючи четвертий том зібрання творів Марка Вовчка, Олександр Дорошкевич передрукував поданий у виданні Лепкого епістолярій, доповнивши його результатами своїх розшуків. Наступними етапами стали зібрання творів письменниці у шести (1955-1956) і семи (1964-1967) томах, кожне 3 яких містило низку невідомих раніше листів. Крім видання творів, були й інші публікації, які запроваджували в науковий обіг нові листи. Одним із найбільших став підготовлений Ніною Крутіковою корпус листів Марка Вовчка до Івана Тургенєва, до якого ввійшло сорок вісім позицій, із них сорок дві публікувалися вперше ${ }^{1}$. Друкувалися також статті, присвячені епістолярію Марка Вовчка ${ }^{2}$. На сьогодні кореспонденція Марка Вовчка майже вичерпно представлена у виданнях Листи Марка Вовчка ${ }^{3}$ та Листи до Марка Вовчка ${ }^{4}$. Крім Шевченка, чиї листи не раз публікувалися, а вхідна кореспонденція мала два видання [Листи до Т.Г. Шевченка (1962) і Листи до Тараса Шевченка (1993)], та Марка Вовчка, епістолярній спадщині українських письменників не приділялося стільки уваги (маю на увазі лише завершені проекти і повне листування, а не вибране $з$ кількома кореспондентами).

Не ставлячи собі за мету проаналізувати все листування письменниці, зупинюся лише на невеликій його частині - епістолярному діалозі Марка Вовчка з Василем Доманицьким. Уперше листи Марка Вовчка до Василя Доманицького, оригінали яких зберігалися в академіка Сергія Єфремова, опублікував 1928 року Олександр Дорошкевич у четвертому томі Творів Марка Вовчка 5 . Позаяк Марко Вовчок зверталася до адресата «Шановний пане Добродію» чи «Шановний Добродію», а не по імені, публікатор хибно атрибутував усі ці листи як адресовані Федору Матушевському, очевидно тут мала місце і помилка пам’ яті в акад. Єфремова. Пізніше ці листи ввійшли до шеститомного видання творів письменниці без жодних змін ${ }^{6}$. Натомість

1 Письма М.А. Маркович (Марка Вовчка) (1859-1864), ст. и коммент. Н.Е. Крутиковой [в:] Литературное наследство, т. 73, кн. 2, Москва 1964, с. 249-302. Розгорнуту рецензію на цю публікацію див.: М.Є. Сиваченко, Вагоме поповнення епістолярної спадщчини Марка Вовчка «Радянське літературознавство» 1965, № 1 (січень), с. 43-49.

2 О.О. Білявська. Деякі приничипи датування листів Марка Вовчка «Радянське літературознавство» 1963, № 2 (березень-квітень), с. 98-103. Б.Б. Лобач-Жученко, Про датування листів Марка Вовчка, «Радянське літературознавство» 1965, № 2 (лютий), с. 67-73.

3 Листи Марка Вовчка у двох томах, упор. й прим. Б.Б. Лобача-Жученка та В.О. Дорошкевича, т. 1: Листи 1850-1871; т. 2: Листи 1872-1907, Київ 1984.

4 Листи до Марка Вовчка у двох томах, упорядкування та примітки О.I. Гончара, С.А. Кривошапової, І.Т. Купріянова, Б.Б. Лобача-Жученка, І.П. Мегели, т. 1: Листи 1850-1869; т. 2: Листи 1870-1907, Київ 1979.

5 Твори Марка Вовчка, упорядник О. Дорошкевич, т. , [Київ] 1928, с. 463-465.

6 М. Вовчок. Твори в шести томах, т. 6, упор. О.О. Білявська, Б.М. Мінчин, с. 489, 490, 492, 493. 
упорядники найповнішого на сьогодні видання творів письменниці в семи томах виправили цей недогляд попередників і реатрибутували всі без винятку листи як адресовані Доманицькому․․ Проте, зробивши реатрибуцію всіх листів «одним пакетом», а не кожного окремо, вони й самі припустилися помилок. Згодом у видавництві «Дніпро» побачив світ двотомник Листи Марка Вовчка, який, на жаль, теж не позбавлено хиб. Проба повільного читання самих цих текстів i приміток до них разом та паралельне співставлення їх із біографіями обох кореспондентів викликає низку питань.

Епістолярний діалог Марка Вовчка з Доманицьким почався 3 амбітного проекту видавничого гуртка київських студентів i семінаристів, які запланували видати до ювілею виходу Енеїди Івана Котляревського антологію кращих поетичних творів нової української літератури за сто років. Попри задану наперед неможливість реалізувати такий проект, як згодом згадували видавці ${ }^{8}$, він виявився успішним. Несподіваний успіх антології продемонстрував, що існує підготовлена аудиторія і вона потребує якісної української книжки, «одхилив завісу до того гуртового читача, що мав постачати кошти, купуючи книжки» 9

Неочікуваний великий успіх спонукав видавців негайно взятися за підготовку видання антології, куди, крім поетичних, мали ввійти й прозові твори. Саме робота над прозовими томами антології поклала початок спілкуванню Марка Вовчка з молодими київськими видавцями, зокрема й Доманицьким ${ }^{10}$. Твердження, ніби листування письменниці з Доманицьким зав'язалося 1901 року $^{11}$ чи 1902-го ${ }^{12}$, хибне, адже воно стосувалося підготовки другого тому антології і припало на 1900-1901 роки. Особисте знайомство Марка Вовчка і Доманицького під час ії візиту до Києва влітку 1902 року, так і не відбулася: хворий на сухоти Доманицький саме тоді поїхав лікуватися на південь ${ }^{13}$. У той свій приїзд письменниця відвідала редакцію журналу «Киевская старина», де, зокрема, зустрічалася з Володимиром Науменком і Матушевським ${ }^{14}$.

Епістолярний діалог Марка Вовчка і Доманицького тривав недовго. Перший лист до письменниці датовано 9 жовтня ${ }^{15} 1900$ року, а останній -

7 М. Вовчок. Твори в семи томах, Київ 1967, т. 7, кн. 2, упор. та прим. О.О. Білявської, Б.Б. Лобача-Жученка, с. 259, 261, 264.

8 С. Єфремов. Щоденник. Про дні минулі (спогади), Київ 2011, с. 447-448.

9 Ibid., c. 450.

10 Свого часу я лише побіжно торкався теми спілкування Доманицького з Марком Вовчком, див.: Б. Цимбал. Василь Доманицький - вовчкознавець [в:] Василь Доманицький: особистість i ауково-творча спадщина. Збірник праць учасників наукового семінару, Черкаси 2011, с. 99-105.

11 Б.Б. Лобач-Жученко. Про Марка Вовчка: Сторінки до біографії письменниці, Київ 1979, c. 245 .

12 Б.Б. Лобач-Жученко. О Марко Вовчок: Воспоминания, поиски, находки, Киев 1987, с. 98-99.

13 У літературі трапляються помилкові твердження, що він відбував тоді військову повинність. Див.: Б.Б. Лобач-Жученко. Марко Вовчок на Кавказе (По следам семейного архива), Нальчик 1976, c. 147.

14 Б.Б. Лобач-Жученко. Літопис життя і творчості Марка Вовчка, вид. 2-ге, доповнене, Київ 1983, с. 370.

15 Усі дати подаю за старим стилем. 
26 червня 1906 року $^{16}$. Насправді ж він іще коротший, бо між останнім і передостаннім листом, датованим 10 листопада 1901 року, великий часовий розрив ${ }^{17}$. Як випливає з указаних дат, листування тривало рік. Варто пам'ятати, що ми маємо справу лише зі збереженим епістолярієм, тому треба зважати на певну умовність висновків.

Згідно з двотомними виданнями Листів до Марка Вовчка і Листів Марка Вовчка, на сьогодні збереглися й відомі шість листів Доманицького до письменниці: це № 487, 488, 489, 490, 492, 511 ${ }^{18}$. Натомість листів Марка Вовчка до Доманицького маємо лише три за період з 24 жовтня 1900 р. по 29 грудня 1902 р.: № 647, 652, 659'19.

Як уже згадано вище, вперше Доманицький звернувся до письменниці листом від 9 жовтня 1900 року по дозвіл умістити іiі твори в прозових томах антології Вік:

Тепер уже укладена програма 2-го і 3-го томів Віку прозаїчного, який, розуміється, позбувся б усякого справдішнього значіння, якби не містив в собі Ваших цінних творів, відомих од Кавказу до Алтая, од Амура до Дністра. [...] отже, уклінно просимо Вас, високоповажна пані-добродійко, не відмовте нам скористатись Вашими творами для видання (з якими, сподіваємось, не стидно буде показатись нам і в хаті селянина, і в палаці магната $)^{20}$.

Письменниця відповіла на листа 24 жовтня 1900 року і дозволила видавцям узяти в прозові томи антології будь-які її твори ${ }^{21}$. До другого тому антології, де авторка фігурувала не під загальновідомим прибраним ім'ям, а під справжнім прізвищем (у першому шлюбі) Марія Марковичка, увійшли iii оповідання Два сини, Викуп, Максим Гримач, Данило Гурч22.

У наступному листі від 23 листопада 1900 року, дякуючи за «прихильне вітання і ласкавий дозвіл користуватися з Ваших творів», Доманицький знову від імені товариства звертається до Марка Вовчка 3 «уклінним проханням, чи не спромоглися б Ви хоч на коротке оповіданнячко? А може, дещо знайшлося б і з давніших часів», бо товариство задумало «з нового року видати тут-таки, у Києві, збірник-альманах, до якого мають увійти твори белетристичні про стан просвіти і літературний рух на Україні-Русі та інші текучі, живі питання», а «ім'я Ваше і Ваш твір були б найкращою оздобою чи у сім, чи в якім іншім виданні» ${ }^{23}$.

Докладних відомостей, про який саме збірник писав Доманицький, розшукати не вдалося. На думку коментаторів двотомника Листів до Марка Вовчка, йдеться про другий том антології Вiк ${ }^{24}$. Проте в антології

16 Листи до Марка Вовчка..., т. 2, с. 366-367, 401-402.

17 Ibid., c. 372-373.

18 Ibid., c. 366-373, 401, 402.

19 Листи Марка Вовчка..., т. 2, с. 383, 387, 393.

20 Листи до Марка Вовчка..., т. 2, с. 367.

21 Листи Марка Вовчка..., т. 2, с. 383.

22 Викъ. (1798-1898). Томъ другый. Украинська проза видъ Квиткы до 80-хъ рокивъ ХІХ в., Кыивъ 1902, с. 178-207.

23 Листи до Марка Вовчка..., т. 2, с. 367-368.

24 Ibid., c. 508 
не планувалося друкувати матеріали «про стан просвіти і літературний рух на Україні-Русі та інші текучі, живі питання». Крім того, на мою думку, із самого тексту листа випливає, що Доманицький мав на увазі інше видання, адже на початку речення він згадує антологію Вiк, тому логічніше було б говорити про наступні томи антології, про які він писав у попередньому листі до письменниці ${ }^{25}$, а не про планований «збірникальманах»: «Видавці Віку, Старосвітських батюшок $i$ матушок і т. д. задумали 3 нового року видати тут-таки, у Києві, збірник-альманах» ${ }^{26}$. Якщо Доманицький не помилився в листі щодо змісту «збірника», то цілком імовірно, могло йтися про інше видання, адже за характером він ближче до набагато пізнішого проекту журналу «Вік», який не отримав цензурного дозволу ${ }^{27}$. Можливо, він так і залишився проектом, який припинили ще на доцензурному етапі підготовки. Не могло йтися в листі і про Літературний збірник на спомин про Ол. Кониського, адже Олександр Кониський ще був живий, і цензурний дозвіл на видання датовано роком пізніше - 12 грудня 1901-го ${ }^{28}$. Інший відомий збірник видавництва «Вік» На вічну пам'ять Котляревському отримав цензурний дозвіл 25 жовтня 1903 року ${ }^{29}$. Видання Корифеи украинской сцены отримало цензурний дозвіл 5 грудня 1900 року ${ }^{30}$, і Доманицький надіслав його письменниці 9 травня 1901 року ${ }^{31}$. 3'ясування цього темного місця потребує дальших джерелознавчих розшуків.

Поетична антологія Вiк 1900 року принесла видавництву славу, гроші і навіть назву. Тепер молоді видавці могли розгорнутися на повну силу.

Поплативши борги, - згадував Єфремов, - гурток мав з яку тисячу прибутку - величезний для нас тоді капітал, а опріч того, сталий вже кредит у друкарні, певну репутацію в книгарських сферах і попит од читача. [...] пішли инші видання, - опріч народніх брошурок, вже й справжні книги ${ }^{32}$.

Серед важливих наслідків першого успіху - заснування книжкової серії «Українська бібліотека», окремим виданням у якій вийшли також два томи Народних оповідань Марка Вовчка (1902). Через неповноту джерельної бази дехто з дослідників помилково називали 1902-1903 роки періодом

25 Див.: Листи до Марка Вовчка..., т. 2, с. 366-367.

26 Ibid., c. 368

27 О. Сидоренко, Нездійснені видання: Анотований покажчик нереалізованих проектів україномовних періодичних видань кіния XIX-початку XX cm., Київ 1990, с. 14; Листування Михайла Грушевського, т. 3, упор. Г. Бурлака, Н. Лисенко, Київ-Нью-Йорк-Париж-ЛьвівТоронто 2006, с. 213. (Лист Сергія Єфремова від 28 вересня 1904 р.). С. Сфремов, Щоденник..., c. $559-563$.

28 Литературный збирныкъ зложеный на спомынъ Олександра Кониського. (1836-1900), Кыивъ 1903, с. 2.

29 На вичну пам'ять Котляревському. Литературный збирныкъ, Кыивъ 1904, с. 4.

30 Корифеи украинской сиены. (С 8 портретами), Киев 1901, с. II.

31 Листи до Марка Вовчка..., т. 2, с. 370.

32 С. Сфремов. На світанку українських видавництв. («Вік»), «Бібліологічні вісті» 1925, № $1 / 2$, c. 110 . 
листування письменниці 3 київським видавництвом 3 приводу нового видання Народних оповідань ${ }^{33}$, а насправді воно почалося роком раніше.

У зв'язку з новим проектом Доманицький знову звертається до Марка Вовчка від імені видавництва. У листі до письменниці від 19 лютого 1901 р. він детально розписує плани видавництва, зокрема й щодо підготовки серії «Українська бібліотека», та згадує про традиційні вже цензурні перешкоди й утиски:

видавниче товариство зараз зайнялося іншою, ще більш широкою справою: видати в Росії в цілій серії, під заголовком «Українська бібліотека» писання усіх кращих українських письменників. Се вже ми й почали, хоча назви «Українська бібліотека» на них не поставлено. Бо тільки недавно відвоювали ії у цензури. [...] Але подаючи до цензури твори інших письменників, що мають увійти в «Українську бібліотеку», усякий з нас уже давно думав і говорив: як же це буде «Українська бібліотека» без творів Марка Вовчка! I се цілком справедливо - се була б така прогальовина в нашій серії, якої нічим не можна було б замінити. Отже прошу я і звертаюсь до Вас, високоповажна пані, з серйозним сим питанням: як Ви віднесетесь до сеї справи $?^{34}$

Щоб Марко Вовчок, котра жила тоді з чоловіком в Александровському, добре зрозуміла, про які саме видання і видавництво йдеться, Доманицький «одверто і по щирості» зізнається їй:

ми, видавці, усі люди «учащієся», себто студенти університету та духовних шкіл, народ бідний, почали свої видання в р. 1894, склавши кожен по карбованцеві, а нині все даємо тисячні видання. Уся користь, яка одержується з виданнів, повертається на дальші, чим дальші - все більші і більші видання... ${ }^{35}$

Марко Вовчок не зволікала з відповіддю і через три тижні в листі від 14 березня 1901 року надіслала свою письмову згоду на видання книжки iii творів. Ба більше, кошти, виручені від продажу книжки, вона шляхетно жертвувала на дальший розвиток видавництва «Вік» ${ }^{36}$.

У листі від 9 травня того самого року Доманицький сповіщав Марка Вовчка: «3 Вашого ласкавого дозволу узялись ми й до видання Ваших творів». У молодого дослідника й видавця виникли зауваження стосовно оповідання Маруся, яке в російському виданні мало примітку «переклад 3 малоруського». Доманицький запитував авторку, чи існує український оригінал, щоб надрукувати саме його. У тому самому листі міститьсяпрохання про біографічні матеріали. «Дуже б хотілося, - пише Доманицький, - щоб Ви самі переглянули ці матеріали, а то часто-густо буває, що як почнеш брати їх 3 десятих вуст, то й вийде якась помилка» ${ }^{37}$.

Останній лист до письменниці, у якому Доманицький пише про видавничі справи, датовано 10 листопада 1901 р. У ньому він сповіщав, що збірка творів

33 О. Засенко, Марко Вовчок. (Життя, творчість, місие в історії літератури), Київ 1964, с. 143; О. Засенко. Марко Вовчок. (Нарис життя і творчості) [в:] О. Засенко, Літературнокритичні нариси і статті, Київ 1962, с. 90.

34 Листи до Марка Вовчка..., т. 2, с. 369.

35 Ibid., т. 2, с. 369-370.

36 Листи Марка Вовчка..., т. 2, с. 387.

37 Листи до Марка Вовчка..., т. 2, с. 371 
видатних українських письменників, а серед них і Марка Вовчка, через місяць уже починає друкуватися, та просив повідомити, який із портретів краще взяти до збірника ${ }^{38}$. Зазначені у виданні дата листа й місце написання (Київ) потребують додаткового з'ясування. За спогадами Сергія Єфремова, Доманицький поїхав лікуватися в Ялту 2 жовтня 1901 року ${ }^{39}$, звідки в середині місяця надсилав листи до київських знайомих ${ }^{40}$. Для листування Доманицький часто вказував адресу журналу «Киевская старина». Зазвичай він так робив ${ }^{41}$, якщо лист було написано не на фірмовому бланку редакції історичного щомісячника ${ }^{42}$; це, 3 одного боку, безпосередньо вказує, що листа було написано в Києві, а з другого - ще раз підважує зазначену в листі дату. У виданні Листи до Марка Вовчка, де цей документ опубліковано вперше, жодних зауваг щодо датування упорядники не навели ${ }^{43}$. До цього питання я повернуся пізніше.

Останній лист Марка Вовчка до Доманицького, як його подано у двотомнику (№ 659), датовано 29 грудня 1902 року⒋ Тут, на мою думку, маємо справу з хибною реатрибуцією, що випливає з тексту самого листа. Очевидно, упорядники двотомного епістолярію некритично поставилися до останнього семитомного видання творів Марка Вовчка ${ }^{45}$. На жаль, редактори семитомника проігнорували слушну заувагу Дорошкевича про адресата листа: «Зміст цього листа показує, що він заадресований також до Ф. Матушівського (він учився саме в Дерптському Університеті)» ${ }^{46}$. Імовірно, на такий висновок дослідника наштовхнуло питання Марка Вовчка: «Може, Ви поберетесь, як думали, у Дерпт?» ${ }^{47}$ Ця хибна атрибуція перекочувала із семитомного видання творів Марка Вовчка до Літопису життя й творчості письменниці48. Отже, я припускаю, що останній

38 Ibid., c. 372.

39 С. Єфремов, Чистеє серие [в:] Чистому серием. Пам'яті Василя Доманииького. Біографія, спомини, похорон, упор. С. Єфремов, Київ 1912, с. 22. Про майбутній виїзд Доманицького на південь також згадував Микола Лисенко у листі до Бориса Познанського від 1 жовтня 1901 p. (М.В. Лисенко, Листи, Київ 1964, с. 340.)

40 Див.: Г. Берло, 3 листування Василя Доманицького (1901-2) [в:] За сто літ: Матеріяли з громадського й літературного життя Украӥни ХІХ і початків ХХ століття, кн. I, Київ 1927, с. 227; Інститут рукопису Національної бібліотеки України імені В. І. Вернадського (далі IP НБУВ), Ф. 317 (С. Єфремов), Од. зб. 1811 (В. Доманицький Листи до В. Страшкевича, В. Дурдуківського та С. Сфремова. Машинопис), арк. 3.

41 Див.: Листи до Марка Вовчка..., т. 2, с. 367-371; Российский государственный архив литературы и искусства, Ф. 461 (П. Симони), Оп. 2, Ед. хр. 82 (В. Доманицкий. Письмо к П.К. Симони от [18. I 1900] г.), л. 2.

42 Напр., див.: IP НБУВ, Ф. XXXVI (А. Кримський), Од. зб. 263 (В. Доманицький. Лист до Аг. Кримського від 4. ХІІ 1899 р.), 1 арк; Центральний державний історичний архів України у м. Львів, Ф. 309 (Наукове товариство ім. Шевченка), Оп. 1, Од. зб. 181 (Листи редакцій газет і журналів про обмін виданнями, пересилку літератури та ін. 1898-1900), арк. 7.

43 Листи до Марка Вовчка..., т. 2, с. 509.

44 Листи Марка Вовчка..., т. 2, с. 393.

45 М. Вовчок, Твори в семи томах.., т. 7, кн. 2, с. 264.

46 Твори Марка Вовчка..., т. IV, с. 603-604.

47 Ibid., c. 465; Листи Марка Вовчка..., т. 2, с. 393.

48 Б.Б. Лобач-Жученко, Літопис життя і творчості Марка Вовчка..., с. 373. 
у двотомнику лист Марка Вовчка до Доманицького від 29 грудня 1902 р. насправді адресовано до Матушевського, як це й значиться у виданнях $1928^{49}$ і 1956 років $^{50}$. Оригінал листа зберігається у фонді Марка Вовчка відділу рукописних фондів і текстології Інституту літератури ім. Т. Г. Шевченка ${ }^{51}$, куди він надійшов саме як лист письменниці до Матушевського ${ }^{52}$.

На користь цієї гіпотези свідчать наступні факти. У самому листі йдеться про публікацію в «Киевской старине» оповідання Марка Вовчка Чортова $n р и г о д a$, і навряд чи Доманицький, який із жовтня 1902 р. по березень 1903 р. перебував на Корфу ${ }^{53}$, міг оперативно вирішувати питання публікації матеріалів на сторінках київського щомісячника. Крім того, як це однозначно випливає з листа письменниці, це була її відповідь на лист від 14 листопада 1902 р.: «Благословившись та позичивши очей у Сірка, одписую на Ваш ласкавий лист 14. ХІ сьогодні, 29. XII, та й сьогодні мушу нашвидку» ${ }^{54}$. Очевидно, це відповідь на лист Матушевського від 14 листопада 1902 року ${ }^{55}$.

Письменниця зверталася до адресата загальником «Шановний добродію», що стало однією з причин хибної атрибуції, яку, як згодом писав Борис Борисович Лобач-Жученко, виправили пізніші дослідники. Торкаючись питання листування Марка Вовчка з Доманицьким, зокрема реатрибуції, він писав:

зіставлення дат і змісту перших двох листів Доманицького й відповідей Марії Олександрівни свідчать, що останні були адресовані саме йому. Позаяк Доманицький давав зворотну адресу на редакцію «Киевской старины», то відповіді на його листи із звертанням «Шановний пане добродію» і «Шановний добродію» могли опинитися в будь-якого члена редакції, що і ввело в оману Дорошкевича ${ }^{56}$.

Заувага, що листи до Доманицького згодом могли опинитися у будь-кого 3 редакції журналу, цілком слушна, проте реатрибуція інших, крім перших двох листів, як адресованих Доманицькому зовсім необгрунтована. До того ж вибіркове урахування факту, що листи, надіслані Доманицькому до редакції щомісячника, могли опинитися у будь-кого 3 працівників журналу, не дозволило спростувати ще кілька хибних атрибуцій, про що далі. Передусім розгляну вади «пакетної» реатрибуції всього епістолярію за двома першими листами.

Після від’їду Доманицького на лікування секретарем редакції журналу «Киевская старина» став Сергій Єфремов, а влітку 1902 року, коли

49 Твори Марка Вовчка..., т. IV, с. 464-465.

50 М. Вовчок, Твори в шести томах..., т. 6, с. 492-493.

51 Відділ рукописних фондів і текстології Інституту літератури ім. Т.Г. Шевченка НАН України (далі - ІЛ), Ф. 4 (Вовчок М.), Од. зб. 28 (М. Вовчок. Лист до Ф. Матушевського від 29. XII [1902] р.), 2 арк.

52 Див.: ІЛ, Обліково-фондова документація, Книга актів та листування (1933-1942), Акт від 26. IV 1940 р., арк. 240.

53 Див. його листи до М.С. Грушевського за цей період: Листування Михайла Грушевського..., c. 319-327.

54 Листи Марка Вовчка..., т. 2, с. 393.

55 Листи до Марка Вовчка..., т. 2, с. 374-375.

56 Б.Б. Лобач-Жученко, Про Марка Вовчка..., с. 245-246. 
письменниця приїздила до Києва, його на цій посаді вже заступив Федір Матушевський. 3 єдиного вцілілого до сьогодні листа Матушевського до Марка Вовчка випливає, що він перебрав на себе листування 3 письменницею після виїзду Доманицького. У листі йдеться про справи, пов'язані з видавництвом «Вік» та публікацією казки Чортова пригода на сторінках «Киевской старины» ${ }^{57}$, тож зміст, мабуть, став ще однією з причин помилки. Крім помилки з реатрибуцією адресата, до двотомного видання Листи до Марка Вовчка не ввійшов ще один лист письменниці до Єфремова від 9 лютого 1903 p. ${ }^{58}$, у якому вона згадує про свій лист до Матушевського, - i це додатковий аргумент для реатрибуції листа. Тематика останнього листа до Матушевського за січень 1903 року, який не ввійшов до двотомника листів письменниці, а вперше його надрукував Дорошкевич ${ }^{59}$, залишається в руслі попередньої кореспонденції: письменниця дякує за надіслані книжки та повідомляє, що навряд чи встигне прислати до кінця січня оповідання. Дату листа встановлено за збереженим оригіналом -8 січня 1901 року ${ }^{60}$.

Припускаю, що лист Марка Вовчка, який традиційно атрибутують як лист до Володимира Науменка (умовно датується другою половиною грудня 1902 р.) $)^{61}$, насправді теж адресовано Матушевському. Уперше лист надрукував Дорошкевич і умовно датував його кінцем 1902 - початком 1903 року $^{62}$. Упорядники двотомника Листів Марка Вовчка датували лист кінцем грудня 1902 року, «за припущенням, що цей лист був написаний незабаром після листа 657» ${ }^{63}$. Лист 657 - це лист письменниці до Науменка від 16 грудня 1902 р., у якому вона звертається з проханням до редактора журналу перерахувати належний їй за Чортову пригоду гонорар на користь петербурзького «Общества имени Т. Г. Шевченко». Науменко відписав 5 січня 1903 p. ${ }^{64}$, повідомивши, що прохання Марка Вовчка виконано. Однак у його відповіді нічого немає про надсилання найближчим часом оповідання для публікації в журналі, а фразу «Позвольте надеяться, что Вы и впредь не откажете „Старине” в своей работе с ней» ${ }^{65}$ навряд чи можна співвіднести зі словами «Здається, не матиму спромоги прислати оповідання до кінця січня. Проте постараюся» ${ }^{66}$ із недатованого листа письменниці з «другої половини грудня 1902 р.». За змістом він більше схожий на доповнення до іiі листа від 29 грудня 1902 р. до Матушевського ${ }^{67} .3$ початку листа («Ви ще, мабуть,

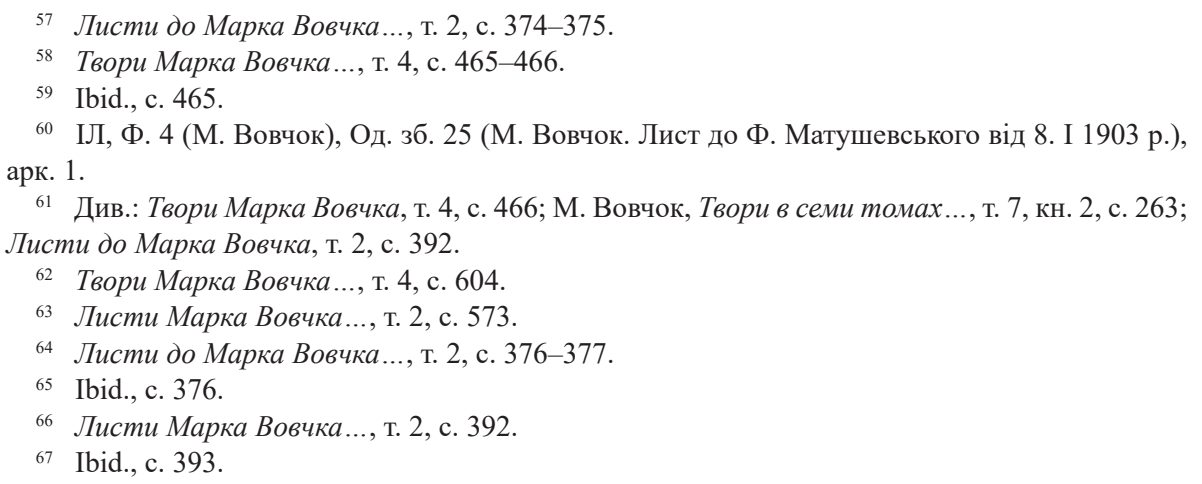


не відібрали мого листа, а я вже поспішаю з другим») випливає, що його надіслано невдовзі після попереднього, на що звертали увагу дослідники ${ }^{68}$, тому припущення, ніби це «post scriptum» до листа від 16 грудня 1902 р. до Науменка, небезпідставне. Проте за змістом ця коротка епістола стає зрозумілою, якщо іії було написано невдовзі після листа від 29 грудня 1902 р. i надіслано до того самого адресата - Матушевського. Фотокопія чернетки (?) листа має дату 8 січня 1903 року ${ }^{69}$.

Крім того, цього листа написано українською, тоді як обидва збережені до сьогодні листи Марка Вовчка до Науменка написано російською, і звертається письменниця до редактора журналу «Уважаемый Владимир Павлович!»70. В аналізованому ж листі фігурує звертання «Шановний добродію!» ${ }^{71}-$ так вона зверталася до Доманицького ${ }^{72}$, Єфремова $^{73}$ і Матушевського $^{74}$.

Інша усталена хибна атрибуція пов'язана зі ще одним листом Марка Вовчка. Від першої публікації 1928 року цей лист відомий як лист до Науменка (писаний рукою Михайла Дем'яновича Лобача-Жученка і лише підписаний Марком Вовчком, яка перед цим хворіла на очі), він умовно датується лютим-березнем 1901 року ${ }^{75}$. Причина цієї атрибуції очевидна і пов'язана 3 тим, що лист зберігся серед матеріалів редактора журналу «Киевская старина», на підставі чого Дорошкевич і атрибутував його ${ }^{76}$. За словами сина письменниці, Марко Вовчок познайомилася з Науменком улітку 1902 р., коли відвідала Київ ${ }^{77}$. Цей факт ставить під сумнів правильність традиційного датування. Однак у цьому випадку немає жодних свідчень, зокрема й ранішого листування, що підтвердили б якісь контакти письменниці з Науменком. Це може вказувати як на неповноту джерельної бази, так і на правильність припущення, що листа насправді адресовано іншій особі. Наприклад, Доманицькому, і у мене є всі підстави це стверджувати.

У двотомнику листів Марка Вовчка вказано традиційне умовне датування листа лютим-березнем 1901 року $^{78}$. Листа написано російською, на відміну від інших листів Марка Вовчка до Доманицького, але за змістом це пряма відповідь на його лист від 9 травня 1901 р., у якому він запитував про український оригінал Mapyci, джерела біографії письменниці (на іï думку,

68 Ibid., c. 573 .

69 ІЛ, Ф. 4 (М. Вовчок), Од. зб. 429 (М. Вовчок. Лист до Ф. Матушевського від 8. I 1903 р.), арк. 1.

70 Див.: Листи до Марка Вовчка..., т. 2, с. 392, 394.

1 Листи Марка Вовчка..., т. 2, с. 392.

2 Ibid., т. 2, c. $383,387$.

Твори Марка Вовчка..., т. 4, с. 465-466.

Ibid., с. 464-465; Листи Марка Вовчка..., т. 2, с. 393.

О. Дорошкевич ніяких припущень щодо датування не подав й опублікував листа без дати (див.: Твори Марка Вовчка, т. 4, с. 467-468). Уперше датували його упорядники шеститомного видання, вказавши лише рік написання - 1901 (див.: М. Вовчок. Твори в шести томах, т. 6, с. 490). Цю ж дату з уточненням до «лютий-березень» повторено й у семитомнику (див.:

М. Вовчок, Твори в семи томах..., т. 7, кн. 2, с. 262-263).

76 Твори Марка Вовчка..., т. 4, с. 604.

77 Б.А. Маркович. Марко Вовчок на Кавказе, Ставрополь 1913, с. 58.

78 Листи Марка Вовчка..., т. 2, с. 386. 
біографію письменника слід писати вже по його смерті) та портрет для видання ${ }^{79}$. Б.Б. Лобач-Жученко, один 3 упорядників двотомника листів письменниці, у підготовленому ним Літописі життя $і$ творчості Марка Вовчка датував лист травнем-червнем 1901 р., також адресуючи його Доманицькому. При цьому він покликався на семитомне видання творів письменниці ${ }^{80}$, хоча у відповідному томі епістолярію він значиться як лист до Володимира Науменка ${ }^{81}$.

У листі згадано, зокрема, портрет письменниці, що його надіслав Доманицькому М.Д. Лобач-Жученко ${ }^{82}$. У листі від 10 листопада 1901 р., який викликає сумніви в правильності датування ${ }^{83}$ (див. вище), Доманицький знову запитує про портрет. Можливо, на той момент він ще не отримав його. Додаткові відомості дозволили б точніше датувати цей лист письменниці та 3'ясувати питання $з$ датуванням листа Доманицького. На початку листа він пише, що другий і третій томи антології української літератури дозволено до друку, і це не суперечить істині, але на другий том петербурзька цензура видала дозвіл 22 червня 1901 року ${ }^{84}$, а на третій -25 липня 1901 року ${ }^{85}$. Крім згадки про цензурний дозвіл на томи антології Вік, маємо в листі ще один важливий факт, про який пише Доманицький, - це відіслані в цензуру твори Марка Вовчка: «Твори Ваші ці уже давненько послали до цензури, але ще відповіді немає. Коли дістану, поспішуся повідомити Вас про сеє ${ }^{86}$. Цензурний дозвіл на перший том Народних оповідань було видано 13 вересня 1901 року $^{87}$, а на другий том ще раніше - 30 липня 1901 року $^{88}$. Імовірно, в цьому випадку маємо справу 3 хибним датуванням, а без додаткових джерельних розшуків чи без залучення оригіналу листа це питання неможливо з'ясувати. Ознайомлення з оригіналом дає чітку й однозначну відповідь: лист написано 10 вересня 1901 року ${ }^{89}$. При підготовці до видання

79 Листи до Марка Вовчка..., т. 2, с. 370-371.

80 Б.Б. Лобач-Жученко, Літопис життя і творчості Марка Вовчка..., с. 367-368.

81 М. Вовчок, Твори в семи томах..., т. 7, кн. 2, с. 262-263. Хибна атрибуція листа потрапила й у праці дослідників. Напр., Олекса Засенко хибно вважав, що згадку про український оригінал Марусі пов'язано з публікацією творів письменниці в журналі «Киевская старина» (О. Засенко, Марко Вовчок. (Життя, творчість, місие в історії літератури)..., с. 143-144). Також див.: Б.В. Хоменко, Епістолярні твори Марка Вовчка в контексті ідейно-художніх пошуків письменниці [в:] Марко Вовчок. Статті і дослідження: Збірник наукових праць, Київ 1985 , с. 114.

82 Листи Марка Вовчка..., т. 2, с. 386.

83 Раніше, покладаючись на авторитетність видання, я беззастережно вважав, що листа написано в листопаді. Див: Б. Цимбал, оp. cit., с. 102.

84 Викъ. (1798-1898), т. II..., с. 2.

85 Викъ. (1798-1898). Томъ третій. Украинська проза зъ 80-хъ рокивъ ХІХ в. до останнихъ часивъ, Кыивъ 1902, с. 2.

86 Листи до Марка Вовчка..., т. 2, с. 372.

87 М. Вовчок, Народни оповидання, т. І, Кыивъ 1902, с. 2.

88 М. Вовчок, Народни оповидання, т. II, Кыивъ 1902, с. 2.

89 Рукописный отдел Института русской литературы (Пушкинский Дом), 9471. LVIб. 7, л. 9. За інформацію про оригінал листа висловлюю щиру вдячність А.Ю. Соловйову. 
трапилася помилка (т. зв. czeski błąd), коли при копіюванні помилково написали замість вересня (IX) - листопад (XI).

При такому датуванні стає зрозумілим, чому Доманицький пише Марку Вовчку, що немає відповіді цензури 3 приводу двотомника Народних оповідань, адже хоч на другий том і був дозвіл, на перший його видали лише через три дні після написання цього листа. А за три дні до цього, 7 вересня, Петербурзький цензурний комітет сповістив Головне управління в справах друку про можливість дозволити видання обох томів Народних оповідань ${ }^{90}$. Саме відсутність цього рішення і затримка $з$ видачею дозволу могли бути причиною того, чому Доманицький не уточнив, що на один із томів дозвіл уже мають: можливо, просто не хотів заплутувати адресатку непотрібними їй подробицями.

Дивним видається зволікання з портретом письменниці, проте маємо й інші документи у цій справі. «Лопросіть дідуся Данила [Мордовця] портрети для Віку та присилайте разом з кліше Шевченка», - писав Сфремов iз Києва до Лотоцького в Петербург 5 вересня 1901 року ${ }^{91}$. Ба більше, друк видання затягувався і Лотоцький писав до Михайла Грушевського з приводу його портрета в антології аж наприкінці року - 5 грудня $1901 \mathrm{p} .^{92}$, бо раніше надіслане Грушевським фото погано надавалося для репродукції у виданні. Тож хоча станом на кінець липня видавці мали цензурний дозвіл на нові томи, підбір портретів письменників для ілюстрування антології тривав і Марко Вовчок не стала винятком.

Останній із відомих на сьогодні листів Доманицького до Марка Вовчка від 26 червня 1906 року не стосується творчості самої письменниці, а пов'язаний із роботою дослідника над підготовкою до видання Кобзаря Тараса Шевченка:

Видання це доручено мені, і я тепер перечитую та перевіряю, де які єсть автографи Т. Г. Відомо мені, що і у Вас, високоповажна Маріє Олександрівно, повинен бути автограф «Неофітів» [...]. Бажаючи, щоб повне видання «Кобзаря» було разом 3 тим як можна правдиве, без помилок, я і звертаюсь до Вас з проханням, знаючи прихильність Вашу до національної справи взагалі і до пам'яті Кобзаря нашого зосібна, - чи не були б Ви такі ласкаві надіслати рекомендованим листом той автограф мені на перегляд, а я зараз же перевіривши його, поверну його Вам назад, на то даю «клятвенное обещание $»^{93}$.

На жаль, відповідь не збереглася, якщо вона й була.

На початку статті я зазначив, що на сьогодні відомі лише три листи Марка Вовчка до Доманицького. Це саме можу повторити й тепер із тією лише невеликою різницею, що це № 647, 651, 652 за період від 24 жовтня 1900 року

90 Б Б. Лобач-Жученко, Літопис життя і творчості Марка Вовчка..., с. 368.

91 Центральний державний історичний архів України у м. Київ, Ф. 1225 (О. Лотоцький), Оп. 1. Од. зб. 58 (Листи та листівки до О. Лотоцького), арк. 13.

92 Центральний державний історичний архів України у м. Київ, Ф. 1235 (Грушевські),

Оп. 1. Од. зб. 613 (Лотоцький О.Г. Листи до М.С. Грушевського), арк. 58-59 зв.

93 Листи до Марка Вовчка..., т. 2, с. 401. 
по 14 березня 1901 року ${ }^{94}$. Так само незмінною залишається кількість листів Доманицького до письменниці - шість (№ 487, 488, 489, 490, 492, 511) із тією різницею, що написано їх протягом 9 жовтня 1900 року - 10 вересня 1901 року і один лист від 26 червня 1906 року ${ }^{95}$.

Натомість маємо суттєве, як на невеликий обсяг, скорочення кількості листів Марка Вовчка до Володимира Науменка з чотирьох до двох позицій (№ 657, 661) ${ }^{96}$ і повернення в перелік адресатів Федора Матушевського, якому адресовано два листи письменниці (№ 658, 659) ${ }^{97}$.

Крім того, до видання не ввійшов ще один (третій) лист Марка Вовчка до Матушевського від 8 січня 1903 року ${ }^{98}$, до Єфремова від 9 лютого 1903 року ${ }^{99}$ та три листи від Пантелеймона Куліша ${ }^{100}$, які на час появи видання листів до письменниці зберігалися в архіві-музеї Української Вільної Академії Наук у США й, очевидно, були невідомі і недоступні упорядникам, на відміну від згадуваних листів до Єфремова та Матушевського.

\section{Бібліографрія}

Берло Г., 3 листування Василя Доманицького (1901-2) [в:] За сто літ: Матеріяли з громадського й літературного життя Украӥни XIX $і$ початків XX століття, кн. І, Київ 1927, с. 227-232.

Білявська О.О., Деякі принџипи датування листів Марка Вовчка «Радянське літературознавство» 1963, № 2 (березень-квітень), с. 98-103.

Викъ. (1798-1898). Томъ другый. Украинська проза видъ Квиткы до 80-хъ рокивъ ХІХ в., Кыивъ 1902.

Викъ. (1798-1898). Томъ третій. Украинська проза зъ 80-хъ рокивъ ХІХ в. до останнихъ часивъ, Кыивъ 1902.

Вовчок М., Народни оповидання, т. I, Кыивъ 1902.

Вовчок М., Народни оповидання, т. ІІ, Кыивъ 1902.

Вовчок М., Твори в семи томах, т. 7, кн. 2, упор та прим. О.О. Білявської, Б.Б. Лобача-Жученка, Київ 1967.

Вовчок М., Твори в шести томах, т. 6, упор О.О. Білявська, Б.М. Мінчин, Київ 1956.

С. Сфремов. На світанку украӥнських видавництв. («Вік»), «Бібліологічні вісті» 1925 , № $1 / 2$, с. 109-111.

Єфремов С., Чистеє серие [в:] Чистому серием. Пам'яті Василя Доманииького. Біографія, спомини, похорон, упор С. Єфремов, Київ 1912, с. 16-30.

\footnotetext{
94 Листи Марка Вовчка..., т. 2, с. 383, 386, 387.

95 Листи до Марка Вовчка..., т. 2, с. 366-373, 401, 402.

96 Листи Марка Вовчка..., т. 2, с. 392, 394.

7 Ibid., c. 392, 393.

98 Твори Марка Вовчка..., т. 4, с. 465.

99 Ibid., c. 465-466.

100 ІЛ, Ф. 1 (Т. Шевченко), Од. зб. 1132 (П. Куліш. Лист до Марії Маркович від 13. VII 1857 р.), 2 арк.; Од. зб. 1133 (П. Куліш. Лист до Марії Маркович; б. д.), 2 арк.; Од. зб. 1134 (П. Куліш. Лист до Марії Маркович; б. д.), 2 арк.
} 
Єфремов С., Щоденник. Про дні минулі (спогади), Київ 2011.

Засенко О., Марко Вовчок. (Життя, творчість, місие в історії літератури), Київ 1964.

Засенко О., Марко Вовчок. (Нарис життя і творчості) [в:] О. Засенко, Літературно-критичні нариси і статті, Київ 1962, с. 7-97.

Корифеи украинской сиены. (С 8 портретами), Киев 1901.

Лисенко М.В., Листи, упор, прим та ком О. Лисенка, вступ. стаття М. Рильського, загальна редакція Л. Кауфмана, Київ 1964.

Листи до Марка Вовчка у двох томах, упор та прим O.I. Гончара, С.А. Кривошапової, І.Т. Купріянова, Б.Б. Лобача-Жученка, І.П. Мегели, т. 1: Листи 1850-1869; т. 2: Листи 1870-1907, Київ 1979.

Листи Марка Вовчка у двох томах, упорядкування й примітки Б.Б. ЛобачаЖученка та В.О. Дорошкевича, т. 1: Листи 1850-1871; т. 2: Листи 18721907, Київ 1984.

Листування Михайла Грушевського, т. 3, упор. Г. Бурлака, Н. Лисенко, КиївНью-Йорк-Париж-Львів-Торонто 2006.

Литературный збирныкъ зложеный на спомынъ Олександра Кониського. (18361900), Кыивъ 1903.

Лобач-Жученко Б.Б., Літопис життя і творчості Марка Вовчка, вид 2-ге, доповнене, Київ 1983.

Лобач-Жученко Б.Б., Марко Вовчок на Кавказе (По следам семейного архива), Нальчик 1976.

Лобач-Жученко Б.Б., О Марко Вовчок: Воспоминания, поиски, находки, Киев 1987.

Лобач-Жученко Б.Б., Про датування листів Марка Вовчка, «Радянське літературознавство» 1965, № 2 (лютий), с. 67-73.

Лобач-Жученко Б.Б., Про Марка Вовчка: Сторінки до біографії письменниці, Київ 1979.

Маркович Б.А., Марко Вовчок на Кавказе, Ставрополь 1913.

На вичну пам'ять Котляревському. Литературный збирныкъ, Кыивъ 1904.

Письма М.А. Маркович (Марка Вовчка) (1859-1864), ст. и коммент. Н.Е. Крутиковой [в:] Литературное наследство, т. 73, кн. 2, Москва 1964, c. 249-302.

Сиваченко М.Є., Вагоме поповнення епістолярної спадщини Марка Вовчка, «Радянське літературознавство» 1965, № 1 (січень), с. 43-49.

Сидоренко О., Нездійснені видання: Анотований покажчик нереалізованих проектів украӥномовних періодичних видань кінця XIX-nочатку XX cm., Київ 1990.

Твори Марка Вовчка, упор О. Дорошкевич, т. 4, [Київ] 1928.

Хоменко Б.В., Епістолярні твори Марка Вовчка в контексті ідейно-художніх пошуків письменниці [в:] Марко Вовчок. Статті і дослідження: Збірник наукових праиьь, відповідальний редактор Р.С. Міщук, Київ 1985, с. 86-114.

Цимбал Б., Василь Доманицький - вовчкознавець [в:] Василь Доманицький: особистість і науково-творча спадщчна. Збірник праць учасників наукового 
семінару, проведеного з нагоди 100-річчя від часу смерті вченого. Черкаси, 14-15 вересня 2010 року, Черкаси 2011, с. 99-105.

\section{Архівні джерела}

ІЛ, Обліково-фондова документація, Книга актів та листування (1933-1942), Акт від 26. IV 1940 р. 411 арк.

ІЛ, Ф. 1 (Т. Шевченко), Од. зб. 1132 (П. Куліш. Лист до Марії Маркович від 13. VII 1857 р.), 2 арк.

ІЛ, Ф. 1 (Т. Шевченко), Од. зб. 1133 (П. Куліш. Лист до Марії Маркович; б. д.), 2 арк. ІЛ, Ф. 1 (Т. Шевченко), Од. зб. 1134 (П. Куліш. Лист до Марії Маркович; б. д.), 2 арк. ІЛ, Ф. 4 (М. Вовчок), Од. зб. 25 (М. Вовчок. Лист до Ф. Матушевського від 8. I 1903 р.), 2 арк.

ІЛ, Ф. 4 (М. Вовчок М.), Од. зб. 28 (М. Вовчок. Лист до Ф. Матушевського від 29. XII [1902] р.), 2 арк.

ІЛ, Ф. 4 (М. Вовчок), Од. зб. 429 (М. Вовчок. Лист до Ф. Матушевського від 8. I 1903 р.), 1 арк.

IP НБУВ, Ф. XXXVI (А. Кримський), Од. зб. 263 (В. Доманицький. Лист до Аг. Кримського від 4. ХII 1899 р.). 1 арк.

ІР НБУВ, Ф. 317 (С. Єфремов), Од. зб. 1811 (В. Доманицький. Листи до В. Страшкевича, В. Дурдуківського та С. Сфремова), 52 арк.

Российский государственный архив литературы и искусства, Ф. 461 (П. Симони), Оп. 2, Ед. хр. 82 (В. Доманицкий. Письмо к П. К. Симони от [18. I 1900] г.), 2 л.

Рукописный отдел Института русской литературы (Пушкинский Дом) Российской академии наук, 9471. LVIб. 7.

Центральний державний історичний архів України у м. Київ, Ф. 1225 (О. Лотоцький), Оп. 1. Од. зб. 58 (Листи та листівки до О. Лотоцького), 15 арк.

Центральний державний історичний архів України у м. Київ, Ф. 1235 (Грушевські), Оп. 1. Од. зб. 613 (Лотоцький О. Г. Листи до М. С. Грушевського), 390 арк.

Центральний державний історичний архів України у м. Львів, Ф. 309 (Наукове товариство ім. Шевченка), Оп. 1, Од. $3 б .181$ (Листи редакцій газет і журналів про обмін виданнями, пересилку літератури та ін. 1898-1900), 16 арк. 